\title{
Taking Another Look at Airline CSR: How Required CSR and Desired CSR Affect Customer Loyalty in the Airline Industry
}

\author{
Yaeri Kim ${ }^{1,+}$, Seojin Stacey Lee ${ }^{2,+}$ and Taewoo $\operatorname{Roh}^{3, *(\mathbb{C})}$ \\ 1 College of Business Administration, Sejong University, Gwang-gaeto Bldg 321, Neungdong-ro 209, \\ Gwangjin-gu, Seoul 05006, Korea; yaerikim17@gmail.com \\ 2 Center for Happiness Studies, Seoul National University, Gwanak-gu, Gwanak-ro 1, Bldg. 220, \\ Seoul 08826, Korea; eternalsj11@gmail.com \\ 3 Department of International Trade and Commerce, Soonchunhyang University, Unitopia 901, \\ Soonchunhyang-ro 22, Sinchang-myeon, Asan-si 31538, Korea \\ * Correspondence: troh@sch.ac.kr \\ + All authors contributed equally to this paper.
}

Received: 5 April 2020; Accepted: 22 May 2020; Published: 23 May 2020

\begin{abstract}
This study aims to take another look at corporate social responsibility (CSR) dimensions in airline industries and identify the moderating effects of socio-economic characteristics on customer loyalty. We applied Carroll's four CSR dimensions and reorganized economic and legal responsibilities under 'required CSR' and philanthropic and environmental responsibilities under 'desired CSR'. The current study reveals that customer loyalty increased when customers perceived airlines to be practicing desired CSR, but not for required CSR. However, this effect varies depending on the expected moderator of socio-economic variables. Regarding required CSR, customers with higher levels of either income or formal education showed increased customer loyalty. However, for desired CSR, only customers with higher levels of education showed significantly increased customer loyalty. Thus, the research findings imply that in order to effectively deliver CSR strategies, airline CSR initiatives also need to take into consideration the socio-economic levels of targeted consumers.
\end{abstract}

Keywords: corporate social responsibility (CSR); desired CSR; required CSR; socio-economic characteristics of consumers; partial least square structural equation model (PLS-SEM)

\section{Introduction}

A good firm that dynamically practices and advocates for corporate social responsibility initiatives, particularly in environmentally conscious ways, has better chances of boosting customer retention rates and creating a positive reputation and attitudes toward the firm [1]. This is even more true in the airline industry. Since aviation firms as a whole have left significant environmental footprints in the past years, they are under immense pressure to curb the harm to the environment and implement environmentally friendly technology and management [2,3]. Reflecting on this trend, global associations such as Tour Operator's Initiative (TOI) and the United Nations World Tourism Organization (UNWTO) have released policies regarding airlines' ethical standards.

Today, the number of eco-conscious consumers in the marketplace is rapidly increasing $[4,5]$. Moreover, customers increasingly want to buy products or services from socially responsible companies that care for the environment, communities, and society [6]. Given such market conditions, the airline firms' bid for environmental corporate social responsibility practices is undoubtedly essential to rouse eco-conscious consumers' loyalty intentions and beneficial behavior from companies [1], which are crucial requirements for successfully managing airlines and generating long-term profits for firms [7]. 
Many airlines have enacted various environmentally sustainable policies due to customers in the airline industry being primarily concerned about environmental corporate social responsibility (CSR) $[2,8]$. However, questions about which CSR responsibilities are perceived as most important to customers, and which responsibilities could potentially influence customer loyalty in certain conditions, have received less attention and remain unanswered in today's existing literature [9].

Previous studies have been more focused on showing the impact of environmentally targeted CSR practices. Although some studies did incorporate Carroll's classic CSR pyramid model and issue specific to the aviation industry, those papers merely ranked CSR dimensions by their levels of impact on customer loyalty, instead of providing insights that explain why there were differing levels of influence within the CSR dimensions $[1,10,11]$. To our knowledge, none of the previous studies used Carroll's second-order constructs investigating the effects of desired CSR and required CSR, respectively, on customer loyalty in the airline industry [12]. Thus, this paper aims to revamp CSR in the airline industry, which could guide researchers and airline managers in better understanding which responsibilities are required/desired by society $[13,14]$. Furthermore, the paper will show how the two different types of CSR practices influence customer loyalty differently and analyze such a phenomenon by applying demographic moderators such as formal education, income levels, and the type of carriers.

In summary, this paper aims to contribute a new CSR model by taking another look at Carroll's pyramid model with the airline-specific issue of environmental responsibility. Additionally, we wish to examine how this new CSR model affects customer loyalty [15]. We will examine the moderating effects of formal education, income levels, and the type of carriers by including it into our research model. Expressly, we assume that the company's CSR practices may be perceived differently by consumers, depending on how each dimension of CSR is perceived as required or desired. We hypothesized the anticipated effects of the new CSR model by reviewing previous CSR literature oriented towards the airline industry. The methodology, how the hypothesis was tested, statistical results, discussion, and conclusion sections would be presented.

\section{Literature Review and Hypothesis Development}

\subsection{Taking Another Look on CSR: Required and Desired Responsibilities by Society}

CSR, which refers to the commitment and activities of a company to enhance the social quality of life, is garnering attention in the business world. Social Responsibilities of the Businessman, published by Bowen [16], first put forth the notion of CSR. With the expansion of conglomerates and rising standards of living through economic development, the idea of CSR gained momentum. Carroll [13] has since further conceptualized CSR thoroughly by highlighting four responsibilities of businesses expected by society: obligations in economic, legal, ethical, and philanthropic realms. Economic responsibility refers to businesses' primary obligation of being the fundamental units of producing society's goods and services. Legal responsibility refers to businesses being expected to conduct their economic operations within legal boundaries. Ethical responsibility, much emphasized in modern times, refers to businesses being expected to conduct themselves above compulsory legal requirements. Lastly, philanthropic responsibility, also known as discretionary responsibility, refers to businesses being expected to carry out social roles for the responsibilities mentioned above. For instance, businesses may carry out formal educational programs targeted towards abusers and create relief funds. CSR comprises of these four categories. Furthermore, Carroll's pyramid model has been developed in diverse areas of research. The consumers' perception of luxury brands' CSR initiatives was investigated based on Carroll's model. Amatulli [17] demonstrated that, among the four dimensions in Carroll's model, the two visible dimensions of legal and philanthropic responsibilities increased consumers' willingness to pay compared to invisible and internal initiatives of economic and ethical. Besides, Carroll's CSR model was utilized in the casino industry to explain casino employees' 
organizational trust, job satisfaction, and customer orientation [18]. The model was even applied in the gaming company [19].

In the midst of the attention given toward Carroll's CSR model in Figure 1, many researchers attempted to modify it to match industry characteristics [20-22]. Carroll [12] asserted a new framework by classifying the four responsibilities under new categories as required, expected/desired by society. Society seems to believe economic and legal responsibilities to be "required" of businesses, ethical responsibility is "expected" of businesses, and philanthropic responsibilities are "expected/desired" of businesses $[13,14]$. First, concerning economic responsibility, businesses are expected and very much required by society to be sustainable, which is only achieved by being profitable, attracting investments from shareholders or owners, and having enough resources to sustain their operations. Profits are crucial both for rewarding investors/owners and expanding business operations when they reinvest their profits back into businesses. Therefore, economic responsibility is seen as a requirement to be fulfilled in this competitive business world [12]. Second, society also establishes fundamental ground rules that businesses are expected to abide by. These ground rules encompass laws and regulations, which echo society's perception of "codified ethics" because they express basic concepts about fair business operations as determined by lawmakers at local, state, and federal levels [23]. Third, the conventional assumption of most societies is that laws are necessary but insufficient. In addition to regulations and legal requirements, society expects ethical conduct and operations from businesses, even in situations where laws provide no direction. Organizations are expected to adopt such activities, norms, and procedures, even if they are not written into law. The ethical expectation for businesses is to follow the implied intention of the law and not just the literal wording of the law [24]. Lastly, the philanthropy of businesses may not constitute a hard responsibility, but it is usually expected by the public today. Obviously, the nature and scope of philanthropic activities are at the businesses' discretion. Businesses' desire to partake in social activities that are not legally required nor usually expected of businesses [25], is what guides them. By endorsing this new CSR approach, the current study extends to the airline industry [25].

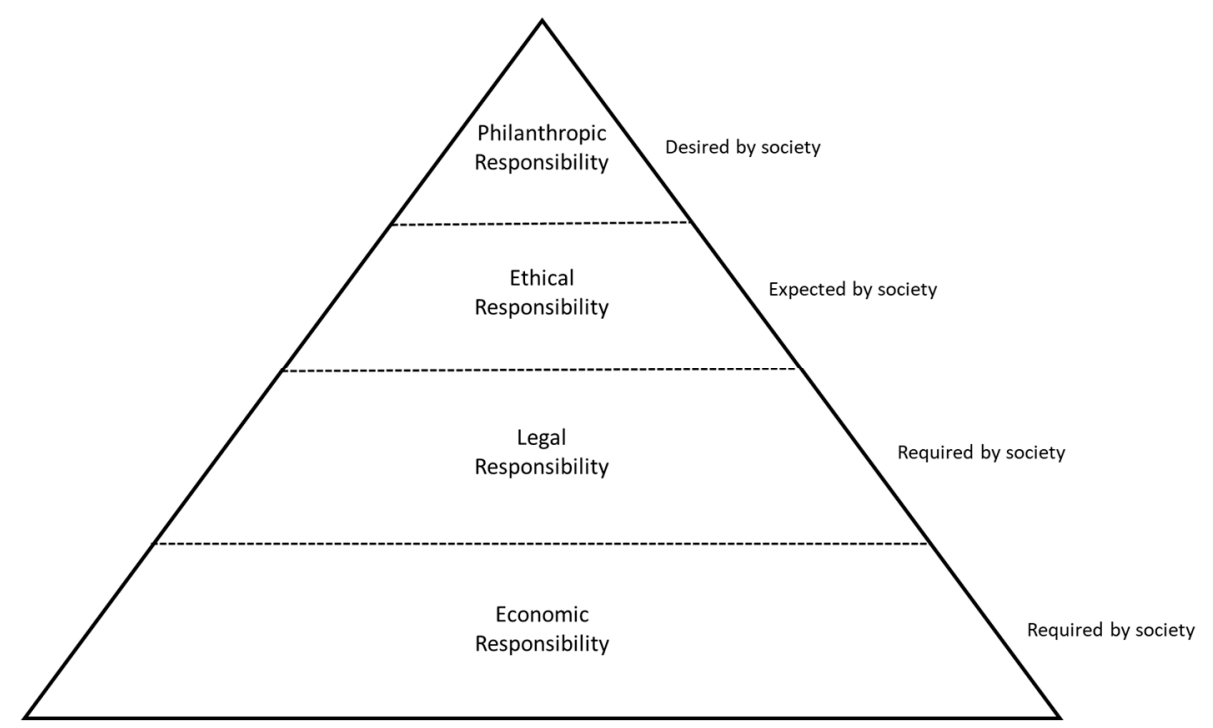

Figure 1. Carroll's modified pyramid of corporate social responsibility (CSR).

\subsection{CSR in the Airline Industry}

Amid rising concerns about pollution, consumers are highly sensitive to environmental issues in every industry. The airline industry faces these concerns even more critically than others because of its close link to heavy fossil fuel usage. Recent research also revealed that, from the consumers' perspective, one of the most critical CSR activities in the airline industry is related to environmental protection, 
along with safety issues [10]. It is quite impressive that consumers consider the environmental responsibility to be as equally concerning safety issues, which potentially determine life and death. Besides, Cowper-Smith and de Grosbois [26] also discovered that CSR reporting contents in the airline industry are skewed towards environmental issues, instead of covering social or economic issues. Emission reductions tend to especially garner most of the attention, while other issues were not highlighted as much.

Accordingly, Carroll's typical pyramid should be adjusted by reflecting the specific characteristics of the industry. Thus, as in the previous studies, environmental CSR was incorporated as an independent dimension to Carroll's original CSR pyramid, in order to contextualize it for the airline industry [15]. Environmental CSR is defined as a particular company's contribution to the environmentally-conscious development of society. Environmental CSR activities are those that are coherent with sustainable methods of preserving the natural environment under the mission of sustainable development [27-29]. According to this definition, environmental CSR falls under being a desired CSR rather than a required one. Environmental regulations and policies that are mandatory to follow are related to legal CSR, but environmental CSR is more related to a corporation's extra efforts.

In addition, as Carroll [12] mentioned, differentiating between legal and ethical responsibilities is often tricky. Legal expectations are indeed based on ethical propositions. However, ethical expectations expand these further. So, essentially, both contain an evident ethical character, and the differentiating characteristic is the mandate society grants businesses through legal confiscation. Rather than open this problem to affect the study model as a limitation, we redefined legal CSR as encompassing a broader meaning, which includes ethical CSR. Thus, we built a CSR pyramid by modifying Carroll's classic model specifically for the airline industry: economic and legal responsibilities as "required by society" and environmental and philanthropic responsibilities as "desired by society."

\subsection{How CSR Affects Customer Loyalty}

Customer loyalty refers to the customers' unwavering commitment to a particular business, and their robust relationship that is unlikely to change under ordinary circumstances [30]. It is a set of actions that signals the customers' intent to maintain the relationship with a particular company, including the repeat purchase of a firm's products or spreading good word-of-mouth [31]. Every business puts great importance on customer loyalty and strives to enhance it. It is essential to a company's long-term growth and maintaining a competitive advantage over competitors [32]. Customers directly impact the profits of businesses, and it has been demonstrated that a $5 \%$ rise in customer loyalty may raise profits in the range of $25 \%$ to $85 \%$ [33].

Customer loyalty consists of behavioral and attitudinal aspects $[27,34,35]$. The behavioral dimension is the repeat purchase behavior of the customer, which indicates a preference for a certain brand over time [33], while the attitudinal dimension is the customer's intent to recommend and repurchase. The behavioral dimension of customer loyalty, i.e., repurchase behavior, may not necessarily indicate customer satisfaction. Repurchasing may be due to a lack of substitutes or switching costs, and this type of repurchasing is merely spurious loyalty. If a customer only has spurious loyalty to a company, repurchase may occur even when a business has a bad reputation [36].

On the other hand, the attitudinal dimension indicates that the company is evaluated positively and has an emotional connection between the company and customers, thus creating real loyalty. This dimension is connected to active loyalty, which induces a desirable word of mouth [36]. It could mean brand commitment, being possible to be described as esteem, trust, or the desire of customers to continue the relationship or obtain the same brand. Therefore, the current study emphasized attitudinal loyalty and applied this concept accordingly in the study method.

The goal of this research is to uncover how required and desired CSR affects customer loyalty. Numerous studies have shown a positive relationship between views of CSR and customer loyalty [37-39]. Some of them have investigated how different types of CSR dimensions affect customer loyalty differently. For example, Stanisavljević [30] discovered that among the four of 
the CSR dimensions, philanthropic ranked as having the strongest influence and economic, legal, and ethical dimensions followed. Chung, Yu, Choi and Shin [32] revealed how each CSR dimension affects customer satisfaction and loyalty based on Chinese consumers. This research paper added consumer protection to Carroll's CSR constructs, for the reason that Chinese people are becoming increasingly worried about consumer protection, which ranked the highest among customers, followed by philanthropic, legal, ethical, economic, and environmental responsibilities. However, there is a lack of research re-categorizing CSR dimensions as required and desired, and finding out their influence on customer loyalty.

Besides, even among studies that looked into how the CSR dimensions affect customer loyalty, such studies simply ranked the CSR dimensions according to their levels of influence on customer loyalty. They did not provide insights that explained why there were differences in the level of influence among the CSR dimensions. Especially in the airline industry, none of the previous studies designed second-order constructs focusing on the effects of desired and required CSR on customer loyalty. Ergo, this paper aims to examine how required and desired CSR practices influence customer loyalty within the airline industry, and also to explain such phenomenon by utilizing moderators. Even though there is a lack of research that directly references desired and required CSR, through the following literature review, we can find clues that help us predict this paper's results.

To begin with, Lho, Park and Yu [11] showed that legal CSR, a required CSR dimension, had minimal impact on brand image, while philanthropic, followed by ethical and economic dimensions, significantly impacted brand image. Of the three dimensions that significantly impacted brand image, philanthropic, and ethical dimensions are desired dimensions. Although this study was conducted in the context of the hotel industry, the findings could apply to airlines as well, since both airlines and hotels are a part of the travel industry. Han, Yu and Kim [1] examined the role that an airline's environmental CSR played in boosting customers' loyalty intentions while using a brand image, love and respect, and customers' existing environmental concerns as mediating factors. They discovered that environmental CSR, the desired CSR dimension, played a significant role in increasing loyalty intentions. Additionally, the customers' pre-existing environmental concerns had a significant influence on their loyalty intentions. These conclusions, since this study was conducted in the context of airlines, may be of great relevance to our research.

Asatryan [10] examined the significance of various CSR practices in the airline industry, and he uncovered that safety is the biggest concern for airline customers, followed by rights for consumers, environmental protection, and social involvement. Both safety and consumer rights usually fall under the legal dimension of CSR due to things like consumer privacy laws and safety regulations. Our paper has determined the legal dimension to be a required CSR dimension, and Asatryan has shown how required CSR affects customer satisfaction. However, this study was conducted with individuals that had many years of experience in managerial positions in the business world, who are familiar with CSR concepts. Thus, this paper's findings may not accurately reflect customers' actual perceptions. Moreover, Atalik and Eratik [40] studied the effects that CSR campaigns of airlines would have on passengers' commitment to their brand. Turkish Airlines was used as a case study. This paper showed that female passengers were more concerned with CSR campaigns, compared to male passengers. An interesting additional finding was that the majority of passengers, while preferring airlines that have a social responsibility, stated that they would not be inclined to pay more money for such an airline [41]. Furthermore, passengers with medium or higher income levels were more likely to pay more money for airlines with CSR initiatives. Although this paper did not differentiate between the various CSR dimensions, it did demonstrate the moderating effect that income could ultimately have on loyalty, and the paper's research was conducted in the context of an airline. Taken together, we can conclude with the following hypotheses. 


\subsection{Moderators}

Socio-economic characteristics of consumers, as well as corporate activities, have significant impacts on consumer decision making. Existing research has found that several socio-economic attributes affect passengers' airline or airport preference [42,43]. For example, occupational status and income level of passengers were significantly associated with their airline and airport choice [44-46]. Moreover, passenger socio-demographic variables and type of carrier (full-service vs. low-cost) affect the choice of airlines [42,47].

Socio-economic factors influence not only the customer's choice of corporate service but also the customer's appreciation of corporate initiatives. Existing studies have revealed that socio-economic attributes (e.g., social class, income, formal education, or occupation) have influenced customer evaluation of the firm's service provided $[48,49]$. Furthermore, previous studies have investigated which socio-economic factors of consumers influence whether they react positively or negatively to CSR activities of companies [50-52]. The findings of some results revealed that consumers with a high level of formal education and income show more favorable attitudes toward the firm's CSR activities $[50,53]$. However, researchers also pointed out that the relationship between consumers' socio-economic characteristics and their responses to CSR initiatives may vary depending on the context [54]. Therefore, in the current research, we explored the socio-economic factors of passengers that may sway the effects of CSR practices on customer loyalty in the airline industry. For a more detailed investigation, we examined consumer characteristics, which are considered particularly crucial in the aviation industry. We included individual socio-economic factors, including formal education level, income, and the types of carriers usually used.

Concerning formal education, previous research showed that the higher the consumers' formal education level, the higher the awareness of CSR activities of companies [55]. Moreover, studies have shown that the link between formal education and green consumers' attitudes is positively related [53,56]. Moreover, Moisescu [57] argued that the more educated consumers are, the stronger the effects of CSR on their consumer loyalty toward the firms in the dairy products market.

As for income, previous studies indicated that the impact of perceived CSR on customer loyalty varies depending on the income of the customer [51,57]. For example, Al-Abdallah and Ahmed [52] showed that higher-income customers showed higher customer loyalty toward the telecommunication firm's CSR activities [52]. Therefore, we expected that the level of formal education and income of passengers moderates the effects of CSR initiatives on customer loyalty in the airline industry.

Formal education and income have been used extensively as moderators in existing studies investigating customer responses to CSR for showing an individual's socioeconomic status. In the current study, the type of carriers mainly used was added as a moderator since it was expected to allude to the socioeconomic status of passengers in the airline industry. Previous studies have shown that customers who choose low-cost carriers have a tendency to want to minimize costs and are sensitive to flight prices and promotion campaigns [47]. Thus, we anticipated that the types of carriers usually used moderates the influence of CSR activities on customer loyalty in the aviation industry.

\section{Research Model and Hypotheses}

As shown in Figure 2, all hypotheses are expressed as a path between first and second-orders, including moderators. All hypotheses are organized as follows. 


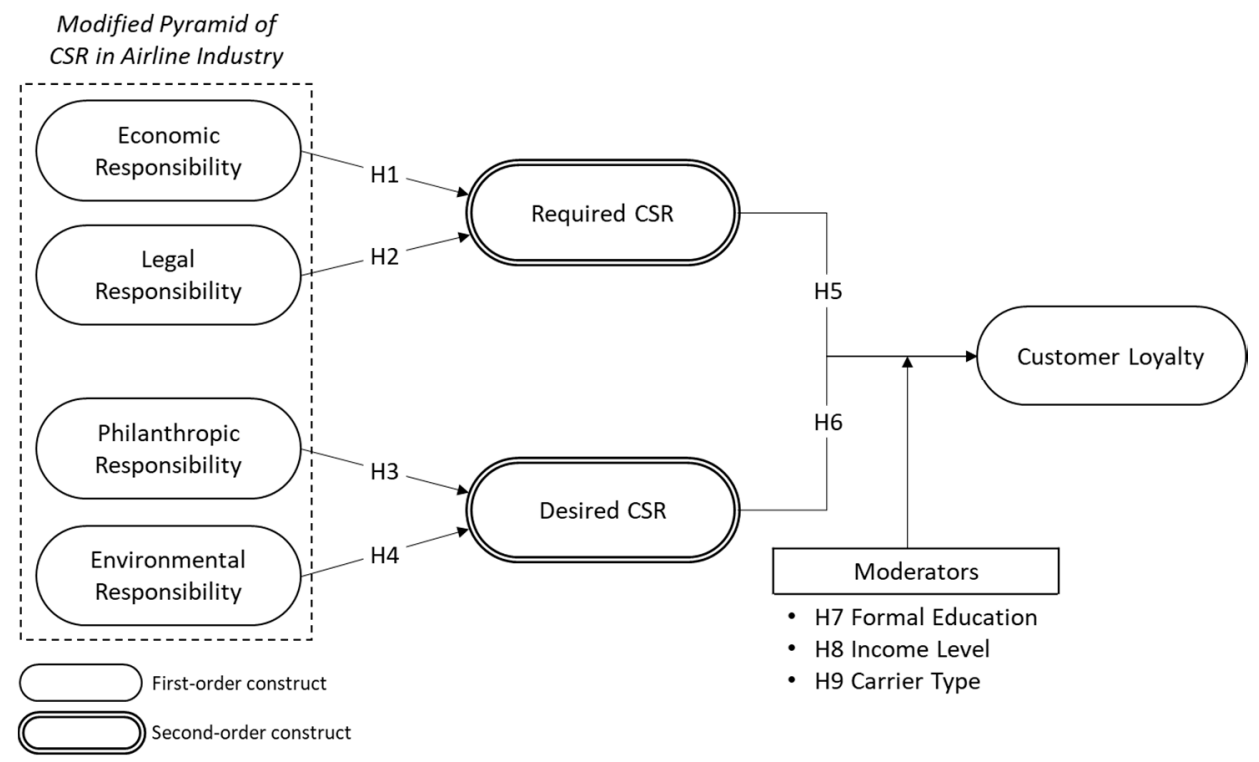

Figure 2. Research model.

Hypothesis 1. Economic responsibility will have a positive effect on the required CSR.

Hypothesis 2. Legal responsibility will have a positive effect on the required CSR.

Hypothesis 3. Philanthropic responsibility will have a positive effect on the desired CSR.

Hypothesis 4. Environmental responsibility will have a positive effect on the desired CSR.

Hypothesis 5. Required CSR will have a positive effect on customer loyalty.

Hypothesis 6. Desired CSR will have a positive effect on customer loyalty.

Hypothesis 7. Formal Education level moderates the influence of required CSR and desired CSR on customer loyalty.

Hypothesis 8. Income level moderates the influence of required CSR and desired CSR on customer loyalty.

Hypothesis 9. Type of preferred carrier moderates the influence of required CSR and desired CSR on customer loyalty.

\section{Methodology}

\subsection{Samples}

In this paper, in order to study how customer loyalty is affected by an airline company's CSR-related initiatives, such as economic/legal responsibilities and philanthropic/environmental responsibilities, we conducted a survey consisting of 19 questions. This survey, created through reviewing current literature, was created to verify the relationship between the airline's economic/legal responsibilities, philanthropic/environmental responsibilities, and customer loyalty. It was conducted at the Incheon International Airport in South Korea for domestic and international airline passengers. Prior to the survey, surveyors inquired participants whether to answer the questionnaire and, then, they asked each question face-to-face and received a reply only when he or she accepted it. Although we emphasized, 
again, that the purpose of the questionnaire was started due to pure academic curiosity, respondents often declined to answer the questionnaire. The participants' demographic characteristics such as gender, marital status, formal educational background, occupation, income, prior experience with airline CSR, and preferred airlines were identified. In order to measure airline passengers' awareness toward airline CSR, we expressly formulated the airline CSR into four categories (e.g., activities for economic, law, philanthropic, and environmental responsibility) and adopted five multiple choice answers for all questions. For example, to improve their understanding of airline CSR, we gave examples of the medical service, disaster relief, and repair work for farming facilities, since environmental CSR activities like fuel-saving projects and global forestry assistance are conducted by charitable airlines. Quick response (QR) codes were used to minimize possible errors in the sampling process and to increase the response rate. The questionnaire in Korean was distributed to people with Korean nationality. Moreover, in order the obtain more accurate answers from respondents, we helped them better understand the CSR activities of airlines by providing various examples. As a result, we obtained a sample size of 200 . We conducted a survey of about 300 people to collect samples and obtained 200 responses (66.7\% response rate). Accordingly, the hypotheses were verified by analyzing the obtained data with the partial least square structural equation model (PLS-SEM) and Multigroup comparison.

\subsection{Variables}

The independent variable is the airlines' CSR initiatives such as environmental, legal, economic responsibilities, and the dependent variable is the customers' loyalty. Carroll [14] defined CSR activities as comprising of economic, legal, ethical, and philanthropic responsibilities. However, in this study, in order to reflect the uniqueness of the airline industry, we reconceptualized the original CSR framework as follows: economic responsibility (EC), legal responsibility (LG), philanthropic responsibility (PH), and environmental responsibility (EV). The addition of environmental responsibility is due to the nature of the airline industry, where aircraft travel vast distances between destinations and produce a substantial carbon footprint. Thus, the airline industry's responsibilities for environmental issues have increasingly become bigger [26,58]. EC refers to the production and sale of goods and services that society wants [14]. Since a firm's nature is to produce profits, EC is of the utmost importance. If a business cannot turn a profit, it cannot contribute to society [59]. LG refers to the minimum rules that companies need to abide and operate. These rules include ethics found in legal, regulatory, or social perspectives that are documented [12]. LG may also appear to go together with EC as a means of implementing fairness and justice [14]. PH focuses on contributing to the community by providing resources and improving the quality of life for citizens, especially the disadvantaged. Being a "good corporate citizen" is emphasized through business activities [14,30]. PH is not only financial support but may also be non-financial support, such as donating food or clothing [60]. According to Carroll [12], PH is the most critical CSR aspect. The next CSR dimension of EC is one of the most pivotal trends in today's business world [61]. The airline industry produces vast amounts of carbon dioxide during operations. The effects of carbon dioxide on the environment at altitudes of $10,000 \mathrm{~m}$ or higher are approximately ten times as severe as they would be at sea level. Hence, ways of minimizing environmental impact have been studied on an ongoing basis in the airline industry [2]. The questionnaire items and related literature used for each variable are shown in Table 1.

Our moderating variables are formal education, income, and carrier. According to Chen and Chao [47], customers whose primary purpose is to travel or those with lower than average income tend to choose low-cost carriers; hence, we hypothesize that the customers' purpose for using airline services will determine carrier choice. Thus, we set income and carrier as moderate variables. According to Rahim, Jalaludin and Tajuddin [55], there is a positive correlation between formal education levels and CSR perceptions. In other words, we hypothesize that the higher the customers' formal education level, the more interest they would show in a corporation's activities. Hence, we also set formal education as a moderator. 
Table 1. The literature on survey items.

\begin{tabular}{|c|c|c|}
\hline Variable & Examples for Question Items & References \\
\hline Economic responsibility & $\begin{array}{c}\text { Firms need to strive to earn profits. } \\
\text { Firms need to maintain a competitive advantage. } \\
\text { Firms need to maintain high levels of operational efficiency. } \\
\text { Firms need to maximize profits. } \\
\text { Firms need to plan for sustained long-term success. } \\
\text { Firms always have to enhance economic results. }\end{array}$ & [63] \\
\hline Legal responsibility & $\begin{array}{c}\text { Firms operate under the government's expectations and the law. } \\
\text { Firms abide by various federal, state, or local laws. } \\
\text { Firms faithfully fulfill their legal obligations. } \\
\text { Firms fulfill the minimum legal requirements regarding products or services. } \\
\text { The company implements rational game rules. } \\
\text { The company follows the set rules. } \\
\text { The company creates appropriate rules for customers to follow. } \\
\text { The company strives to abide by the relevant rules with its customers. }\end{array}$ & [32] \\
\hline Philanthropic responsibility & $\begin{array}{c}\text { Distributing a portion of the profits to charity or local communities. } \\
\text { The company's managers and employees voluntarily partaking in charity. } \\
\text { Supporting the arts, sports, or local festivals. } \\
\text { Providing free services or products to the needy. } \\
\text { This country's CSR is the worst to best. } \\
\text { Thistitity of life. } \\
\text { This country's firms recommend charitable social activities to employees, and } \\
\text { they provide incentives to promote such activities. } \\
\text { In this country, it is natural for individuals or businesses to partake in charities. } \\
\text { Firms in this country often have codes of conduct regarding CSR. }\end{array}$ & [20] \\
\hline Environmental responsibility & $\begin{array}{c}\text { Environmental issues are essential to a business's strategy. } \\
\text { Tackling environmental issues is a necessary part of a business's } \\
\text { everyday operations. } \\
\text { Firms take great care so as not to harm the environment. } \\
\text { Firms continuously gauged their impact on the environment and achieved } \\
\text { short term results. } \\
\text { The hotel recommends environmental conservation and green consumption to } \\
\text { customers, and partakes in related activities. } \\
\text { The hotel has programs in place to maximize energy efficiency or uses facilities } \\
\text { to produce reusable energy such as solar or wind power. } \\
\text { The hotel has programs or facilities in place to minimize contaminated water, } \\
\text { noise pollution, garbage, and white pollution. }\end{array}$ & [66] \\
\hline Customer loyalty & $\begin{array}{l}\text { I strive to buy from companies that help victims of natural disasters. } \\
\text { When shopping, I strive to buy from companies that strive to enhance } \\
\text { employee welfare. } \\
\text { I try to buy from companies that help the unfortunate. } \\
\text { I would pay more when buying from socially responsible corporations. } \\
\text { When shopping, I consider the business's ethical reputation. } \\
\text { I avoid buying from companies that partake in unethical activities. }\end{array}$ & [67] \\
\hline
\end{tabular}

\subsection{PLS-SEM Estimation}

PLS estimation is an analytical technique that applies the factoring technique to observed variables to form a construct and verify the relationship between constructs. PLS finds components that have been optimized through factoring and maximizes variance explained regarding the construct's effect on the dependent variable. Thus, there is no need for normality required in multivariate analysis, and it is relatively unconstrained by sample size. This paper verified a Structural Equation Model (SEM) through the PLS method, using 'plessem' provided by STATA 16. The model verification order is as follows. First, we confirmed for fitness using confirmatory factor analysis (CFA) from the measurement model, and the structural model verified the hypothesis within the construct. CFA assesses the model's reliability, convergent and discriminant validity, and, if there is no problem, verifies the hypothesis. Additionally, even when verifying meaningful results from the structural model, re-verification through bootstrap with a re-sample must be conducted to be considered valid. 


\section{Measurement Analysis}

\subsection{Descriptive Statistics}

The results of surveying 200 consumers that had consumed airline services in the past are shown in Table 2. There were more than twice as many female respondents $(68.5 \%)$ as male respondents $(31.5 \%)$. A service-related job was the most common occupation $(n=94)$, followed by professional workers $(n=60)$, others $(n=31)$, and students $(n=15)$. For formal education levels, those with below a bachelor's degree level (84.5\%) were more than five times as numerous as those with a bachelor's degree or higher (15.5\%). As for monthly income, fewer people had a monthly income of less than KRW 3,000,000 ( $n=76)$, compared to those with an income of KRW 3,000,000 or higher (124). As for airline preference, the number of customers preferring full-size carriers (FSC) (77.0\%) was about three times that of those preferring low-cost carriers (LCC) (23.0\%). Since the $\chi^{2}$ test for measurements of response reliability revealed no significant differences between early respondents and late respondents, the responses are reliable.

Table 2. Demographic statistics.

\begin{tabular}{|c|c|c|c|c|c|c|c|}
\hline \multirow{2}{*}{ Variables } & \multicolumn{2}{|c|}{ Early Respondents } & \multicolumn{2}{|c|}{ Late Respondents } & \multirow{2}{*}{$x^{2}$} & \multirow{2}{*}{$\mathbf{N}$} & \multirow{2}{*}{$\%$} \\
\hline & $\mathbf{N}$ & $\%$ & $\mathbf{N}$ & $\%$ & & & \\
\hline \multicolumn{8}{|l|}{ Gender } \\
\hline Male & 31 & 26.27 & 32 & 39.02 & \multirow{2}{*}{3.65} & 63 & 31.5 \\
\hline Female & 87 & 73.73 & 50 & 60.98 & & 137 & 68.5 \\
\hline \multicolumn{8}{|l|}{ Job } \\
\hline Service & 60 & 50.85 & 34 & 41.46 & \multirow{4}{*}{5.01} & 94 & 47.0 \\
\hline Professional & 35 & 29.66 & 25 & 30.49 & & 60 & 30.0 \\
\hline Student & 10 & 8.47 & 5 & 6.1 & & 15 & 7.5 \\
\hline Others & 13 & 11.02 & 18 & 21.95 & & 31 & 15.5 \\
\hline \multicolumn{8}{|l|}{ Formal education } \\
\hline$<$ Undergraduate & 103 & 87.29 & 66 & 80.49 & \multirow{2}{*}{1.71} & 169 & 84.5 \\
\hline$\geq$ Graduate & 15 & 12.71 & 16 & 19.51 & & 31 & 15.5 \\
\hline \multicolumn{8}{|c|}{ Income (unit: krw/month) } \\
\hline$<3$ million & 48 & 40.68 & 28 & 34.15 & \multirow{2}{*}{0.88} & 76 & 38.0 \\
\hline$\geq 3$ million & 70 & 59.32 & 54 & 65.85 & & 124 & 62.0 \\
\hline \multicolumn{8}{|l|}{ Preferred Airline } \\
\hline Low-cost carrier & 27 & 22.88 & 19 & 23.17 & \multirow{2}{*}{0.00} & 46 & 23.0 \\
\hline Full-service carrier & 91 & 77.12 & 63 & 76.83 & & 154 & 77.0 \\
\hline Total & 82 & 100 & 118 & 100 & & 200 & 100 \\
\hline
\end{tabular}

\subsection{Measurement Model}

Table 3 shows the reliability of the items gathered in each construct, the internal consistency among the items, and the convergent and discriminant validity of the model. In this paper, items that did not exceed a Factor loading of 0.7 were excluded from the measurement in order to obtain high reliability and validity [41]. Accordingly, after certain items had been excluded, 19 items were chosen for additional analysis. All factors had a factor loading that exceeded the recommended figure of 0.7, and Customer Loyalty had the highest CL2 at 0.940. For each item, the mean value was EC (4.22 4.25), LG (4.32 4.52), PH (3.86 4.11), EV (4.25 4.53), and customer loyalty (CL) (3.04 3.63). The standard deviation was found to be less than 1 . 
Table 3. Confirmatory factor loading, mean, and standard deviation.

\begin{tabular}{|c|c|c|c|c|c|}
\hline Construct & Code & Scale Item & Factor Loading & Mean & S.D. \\
\hline \multirow[b]{2}{*}{$\begin{array}{c}\text { Economic } \\
\text { Responsibility }[62,63]\end{array}$} & EC1 & Airlines need to create economic value continuously. & $0.715^{*}$ & 4.22 & 0.63 \\
\hline & EC2 & $\begin{array}{c}\text { Airlines need to contribute to national economic development } \\
\text { through profit-making. }\end{array}$ & $0.851 *$ & 4.22 & 0.62 \\
\hline \multirow[b]{2}{*}{$\begin{array}{l}\text { Legal Responsibility } \\
\qquad[18,32]\end{array}$} & LG2 & Airlines need to practice ethical business management. & 0.734 * & 4.52 & 0.57 \\
\hline & LG3 & $\begin{array}{l}\text { Airlines need to respond sincerely to responding to complaints } \\
\text { about customer satisfaction. }\end{array}$ & $0.833^{*}$ & 4.35 & 0.65 \\
\hline \multirow{3}{*}{$\begin{array}{c}\text { Philanthropic } \\
\text { Responsibility }[20,64]\end{array}$} & PH1 & $\begin{array}{c}\text { Airlines need to make donations and charitable } \\
\text { activities actively. }\end{array}$ & $0.850 *$ & 4.03 & 0.78 \\
\hline & PH2 & $\begin{array}{l}\text { Airlines need to support scholarship projects such as formal } \\
\text { education, culture, and physical formal education. }\end{array}$ & $0.862 *$ & 3.86 & 0.80 \\
\hline & PH3 & Airlines need to do community service well. & $0.886^{*}$ & 3.90 & 0.79 \\
\hline \multirow{4}{*}{$\begin{array}{c}\text { Environmental } \\
\text { Responsibility }[65,66]\end{array}$} & EV2 & $\begin{array}{l}\text { Airlines need to work to improve the environmental damage } \\
\text { due to the characteristics of the aviation industry. }\end{array}$ & $0.748^{*}$ & 4.53 & 0.58 \\
\hline & EV3 & $\begin{array}{c}\text { Airlines need to make additional investments in } \\
\text { environmental responsibility. }\end{array}$ & $0.769 *$ & 4.38 & 0.68 \\
\hline & EV4 & $\begin{array}{l}\text { Airlines need to comply with environmental laws and } \\
\text { regulations and practice environmental management. }\end{array}$ & 0.797 * & 4.41 & 0.61 \\
\hline & EV5 & $\begin{array}{l}\text { Airlines need to participate in environmental protection } \\
\text { activities actively. }\end{array}$ & $0.814^{*}$ & 4.30 & 0.74 \\
\hline \multirow{2}{*}{$\begin{array}{l}\text { Customer Loyalty } \\
{[67,68]}\end{array}$} & CL1 & I will choose an airline that implements CSR activities. & $0.715^{*}$ & 3.04 & 0.98 \\
\hline & CL2 & $\begin{array}{l}\text { I will choose an airline that conducts CSR activities more often } \\
\text { than other airlines that does not. }\end{array}$ & $0.940 *$ & 3.54 & 0.88 \\
\hline
\end{tabular}

Table 4 shows Cronbach's alpha, composition reliability, the relationship between latent variables, average variance extracted (AVE), and the square root of AVE. There can be said to be appropriate internal consistency when Cronbach's alpha and CR are higher than 0.7 [41]. All variables had a CR value of 0.81 or higher, thus displaying appropriate internal consistency.

Table 4. Inter-construct correlations, convergent and discriminant validity.

\begin{tabular}{cccccccccc}
\hline Const & alpha & CR & rho & AVE & EC & LG & PH & EV & CL \\
\hline EC & 0.674 & 0.817 & 0.718 & 0.600 & 0.775 & & & & \\
LG & 0.738 & 0.852 & 0.742 & 0.658 & 0.424 & 0.811 & & & \\
PH & 0.897 & 0.923 & 0.909 & 0.707 & 0.430 & 0.398 & 0.841 & & \\
EV & 0.847 & 0.888 & 0.870 & 0.613 & 0.423 & 0.502 & 0.579 & 0.783 & \\
CL & 0.841 & 0.901 & 0.942 & 0.754 & 0.140 & 0.207 & 0.329 & 0.319 & 0.868 \\
\hline
\end{tabular}

Notes: (1) Const $=$ construct, alpha $=$ Cronbach's alpha, $\mathrm{CR}=$ composite reliability, $\mathrm{AVE}=$ average variance extracted, $\mathrm{RCSR}=$ required CSR, DCSR = desired CSR, EC = economic responsibility, LG = legal responsibility, $\mathrm{PH}=$ philanthropic responsibility, $\mathrm{EV}=$ environmental responsibility, $\mathrm{CL}=$ customer loyalty, (2) italic diagonals are the square rooted value of AVE.

Discriminant validity can be explained to be the AVE value of all variables and was higher than the recommended value of 0.5. Comparing the AVE and square root of AVE, each latent variable's AVE value was higher than the correlation value between the latent variables. It showed a much closer relation to self-measurement than measurements of other variables and shows that this research has discriminant validity $[41,69,70]$. In particular, among the correlation square root values of the latent variables, that between EC and CL (0.635) showed the highest discrimination distance, and that between PH and EV (0.262) was the lowest. 


\subsection{Common Method Bias Test}

The multicollinearity test is usually included as part of the PLS-SEM analysis's question-based data confirmation test. Such tests are known as Common Method Bias (CMB) tests, and they reduce the probability of collinearity related problems, as well as increasing the accuracy of variance-based PLS-SEM estimation that are commonly used in covariance-based methods. Kock [71] asserted that, even if distinct validity was met, due to problems inherent to CMB tests, there must be a process that confirms the collinearity with VIF (Variance Inflation Factor). As Kock and Lynn [72] recommended, this paper's lowest VIF value was 1.35, and the highest was 1.77. Since the highest VIF value did not exceed 5 , there are no collinearity problems.

\section{Results}

\subsection{Structural Model Assessment: PLS-SEM}

We used PLS-SEM to verify the framework which verified the interacting effects between the five first-order constructs, and two second-order constructs derived from four of the original first-order constructs.

Figure 3 shows the PLS estimation results and illustrates the hypothesis in between constructs as paths. In the respective drawing, each path, standardized path coefficient, and explained- $\mathrm{R}^{2}$ can be seen. First, H1 $(\beta=0.541, p<0.001)$ and H2 $(\beta=0.640, p<0.001)$, which run from Economic Responsibility and Legal Responsibility to RCSR, have valid path coefficients and are thus supported. H3 and H4, which run from Philanthropic Responsibility and Environmental Responsibility to desired CSR (DCSR), were also supported within a 0.001 level of significance, and the path coefficients were 0.619 and 0.509 , respectively. However, H5, which runs from RCSR, a second-order construct, to CL, a dependent variable, was not found to be significant $\left(\beta=-0.003, R^{2}=0.117\right)$. H6, running from DCSR to $C L$, was supported $\left(\beta=0.357, R^{2}=0.117\right)$.

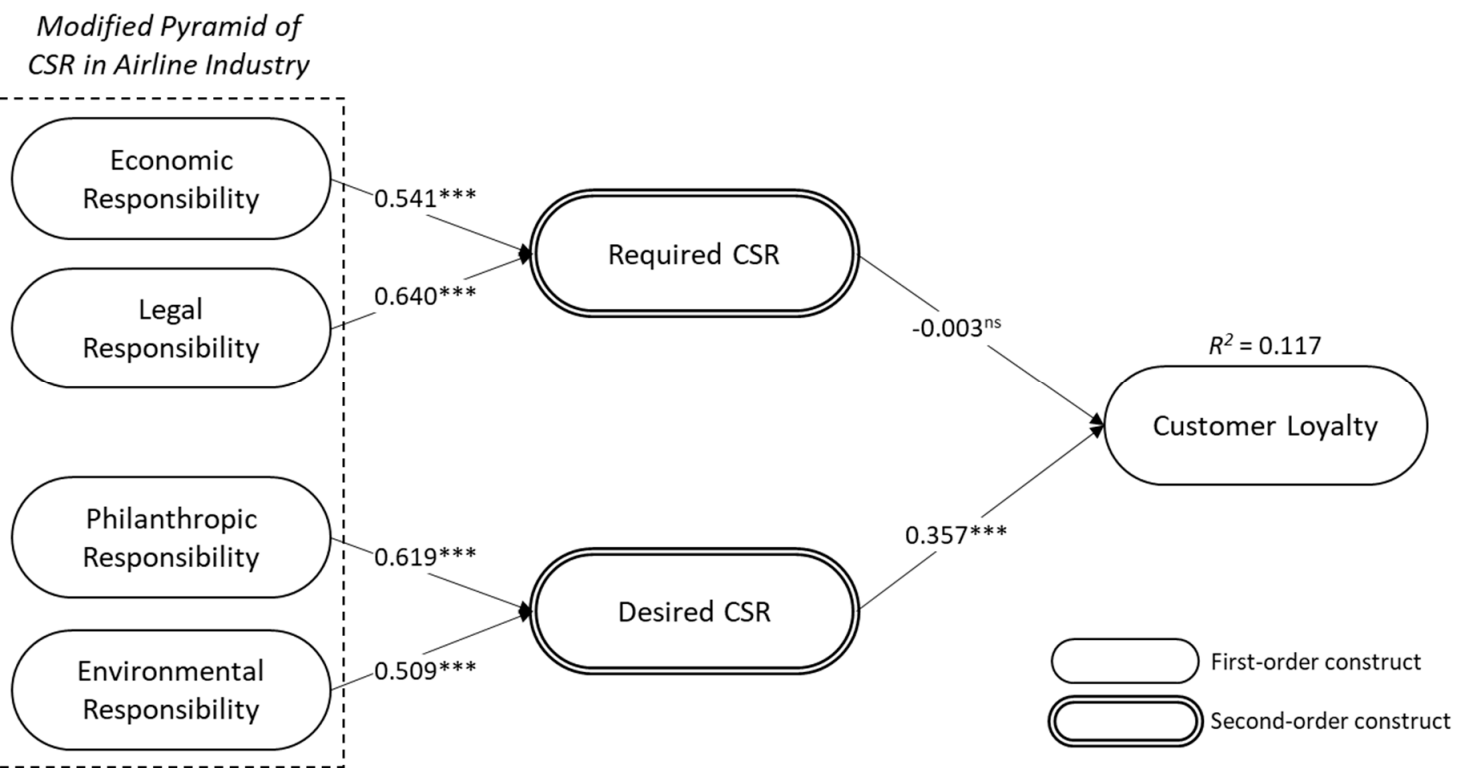

Figure 3. Results of the partial least square structural equation model (PLS-SEM). Notes: (1) Path coefficients are standardized, $(2)^{\text {ns }}$ non-significant, ${ }^{* * *} p<0.001$.

\subsection{Moderation Effect Assessment}

Previously, this paper used the PLS-SEM framework to examine the direct relationships between EC, G, PH, EV, and CL. However, since other factors could influence the paths hypothesized in this study, confirmation related to these factors is prudent. In particular, a detailed analysis of consumer 
psychology based on socioeconomic status (SES) allows many perspectives from which to improve our hypotheses. We hypothesized in this paper that the airline industry consumer's psychological status would be affected by formal education levels, preferred carriers, and income. Chen and Chao [47] have conducted with customers at Kaohsiung International Airport and utilized chi-square analysis to reveal that customers' age, monthly income, travel purpose, and carrier preferences influenced airline choice. A multigroup comparison test (MGCT) can be said to be a useful analysis tool in verifying if the relationship between constructs are the same or have different effects.

According to Table 5, although the path coefficient from required CSR (RCSR) to CL is -0.003 with non-significance, this path is meaningfully affected by three moderators when formal education $(\beta=0.527, p<0.05)$ and income $(\beta=0.490, p<0.05)$ are higher. On the other hand, Preferred carrier, which refers to whether a customer's preferred carrier type is FSC or LSC, did not have a significant effect $(\beta=0.527)$. Upon inspection of the three moderator effects on the path between DCSR and $\mathrm{CL}$, only formal education $(\beta=0.717, p<0.01)$ caused differences from group to group. In summary, upon using MGCT to study the moderating effect of formal education, preferred carrier, and income on the paths that represent the effects of RCSR and DCSR on CL, we can draw the following conclusions. Formal education and income had significant effects on the path between RCSR and CL, and only formal education had significant effects on the path between DCSR and CL. Details on this result will be discussed in the conclusion and future research sections.

Table 5. Multigroup comparison: normal-based $t$-test.

\begin{tabular}{ccccc}
\hline \multirow{2}{*}{ Structural Effect } & Main Effect & \multicolumn{3}{c}{ Moderator } \\
\cline { 3 - 5 } & & Formal Education & Preferred Carrier & Income \\
\hline $\mathrm{RCSR} \rightarrow \mathrm{CL}$ & -0.003 & $0.527^{*}$ & 0.102 & $0.490^{*}$ \\
$\mathrm{DCSR} \rightarrow \mathrm{CL}$ & 0.357 & $0.717^{* *}$ & 0.134 & 0.157 \\
\hline
\end{tabular}

Notes: (1) RCSR = required CSR, DCSR = desired CSR, EC = economic responsibility, LG = legal responsibility, $\mathrm{PH}=$ philanthropic responsibility, $\mathrm{EV}=$ environmental responsibility, $\mathrm{CL}=$ customer loyalty, $(2){ }^{*} p<0.05$, ** $p<0.01$.

\section{Conclusions and Discussion}

\subsection{Summary}

The purpose of the current study was to examine the influence of CSR on customer loyalty and to find the moderating effects of the socio-economic characteristics of passengers in the airline industry. We tested the effects of four types of CSR initiatives on customer loyalty by using the classification of Carroll's pyramid of CSR. Moreover, from a first-ordered construct and its derived second-ordered construct, we created and analyzed a model that shows the effects of required and desired responsibility on customer loyalty by using PLS-SEM. Finally, we investigated the moderating effects of socio-economic factors, such as formal education, income, and carrier types, on the pathway from each of the required and desired CSR to customer loyalty. The theoretical and managerial implications from the findings are discussed below.

\subsection{Theoretical Contributions}

The findings of the current study have several theoretical contributions. First, the current study applied a new framework about required and desired CSR proposed by Carroll [12] to the empirical data. In Carroll's review article, he discussed detailed features of the pyramid model that were not explained when first published [14]. Carroll categorized CSR activities of enterprises into required and desired, according to the nature of each responsibility. The current study made a theoretical contribution by applying Carroll's proposed framework to our empirical data and revealing the different effects of each responsibility on customer loyalty. To the best of our knowledge, little research has utilized the modified pyramid of CSR models to actual empirical data. By showing that the desired 
and required CSR has different impacts on customer loyalty, the results of our empirical research supported that the modified Carroll's pyramid of CSR is valid and useful.

Second, the current study contributes to the literature regarding the impacts of CSR at the customer level by applying the modified pyramid of CSR and providing different effects of each required and desired responsibilities on customer loyalty. As studies on CSR activities in different industries have been actively investigated, studies on CSR activities in the aviation industry are also gradually being examined $[1,15,73]$. An increasing number of airline industry studies have suggested the effects of CSR initiatives both on the corporate level [74-77] and the customer level [10,78], respectively. Existing studies on the impact of CSR on the corporate level have revealed that CSR activities in the airline industry determine corporate financial performance [7,74,79], corporate reputation [77], and commitment levels of employees [80]. On the other hand, previous research focusing on the customer level has consistently suggested that CSR initiatives in the aviation industry cause customers to have favorable attitudes toward the firms $[10,27,78]$. For example, economic, legal, philanthropic, and environmental CSR activities of airlines have positive effects on corporate image, which leads to an increase in customer loyalty [15]. The findings of the present study build on the preceding literature that investigated the separate effects of airline required and desired CSR on passengers' responses at the customer level.

Third, the socio-economic characteristics of passengers were proposed as important moderators that differentiate the effects of the pathway from required and desired CSR to customer loyalty. Some research has suggested that customers with high formal education and high income respond more positively to the firm's CSR activities [50]. However, the scholars pointed out that the relationship between customers' demographic features and attitudes toward CSR would depend on the context. In the current study, how the socio-economic characteristics of passengers moderated the effects of CSR activities on customer loyalty was tested in the airline context. At present, although studies on the CSR of the aviation industry are less focused on CSR strategies to increase customer loyalty [73], the current research can shed light on the CSR strategy literature by suggesting different effects of CSR practices on customer loyalty depending on different socio-economic segmentation.

\subsection{Managerial Implications}

The findings of this research have several managerial implications. One notable practical implication of the current research is that airline managers should pay more attention to desired responsibilities, rather than required responsibilities. The results of the study show that customer loyalty increases when consumers perceive that the airline performs its desired responsibilities, not when it executed its required responsibilities. The results of the current study imply that it is natural and necessary for airline firms to carry out their economic and legal responsibilities from the consumers' point of view; thus, these activities do not affect customer loyalty. Instead, customer loyalty toward the airline increases when the airline is perceived as fulfilling its philanthropic and environmental responsibilities. Due to the industry-wide characteristics of airlines that offer similar experiential services from one company to another, enhancing corporate image and competitiveness through appropriate CSR initiatives is very important for increasing customer loyalty [15]. Therefore, advertisements that indicate the airline company's commitment to ethical and eco-friendly responsibilities for society are more persuasive when it comes to increasing customer loyalty, rather than appealing to the economic and legal superiority of being the top-earning company focused on the firm's bottom line. For example, Korean Air has been working on the Global Plant Project, a tree planting activity to prevent the progress of desertification in Mongolia and to make the earth greener for 16 years. Moreover, Dutch airline KLM has launched a campaign entitled Fly Responsibly, which encourages customers to pack lighter, purchase carbon offsets, and even fly less to protect the environment. The results of the current research suggest that such diverse sustainability initiatives of airlines greatly contribute to enhancing customer loyalty as well. 
Moreover, the findings of the current study provide specific guidelines for airline managers to take different strategies, depending on the socio-economic groups of passengers. A crucial issue that should be regarded by firm managers is finding out which customer groups would be more responsive to certain CSR activities. The results of this study reveal that the higher the formal education level, the more critical the airline's required and desired responsibilities are perceived to be. Therefore, it is vital to advertise CSR activities via communication channels mainly used by highly educated consumers. Moreover, it was suggested that customers with higher incomes tend to place more importance on the airline's required responsibilities. Therefore, emphasizing how successfully the airline's economic and legal CSR activities are implemented in brochures or magazines placed in the first and business classes, mainly used by relatively high-income earners, might be an effective strategy to increase customer loyalty. Taken together, airline firms should consider whether the CSR dimensions are correctly matched with corresponding customer groups when promoting CSR initiatives.

\subsection{Limitations and Future Research}

The current study has several limitations, notwithstanding its significant theoretical and managerial implications. First, the preferred carrier, which was tested one of the potential moderators, did not have a significant effect of both required and desired CSR on customer loyalty in the current model research. We include this variable since the carrier type is a unique and noteworthy factor that could show passengers' socio-economic status and could be investigated in the airline industry only. In a future study, this factor can be measured as a continuous rather than a dummy variable, as we did in the current study. By measuring the carrier type as a continuous variable assessing the provided service level of aircrafts, information about the significant effect of this variable on customer loyalty can be provided in the future study. Second, there was a significant moderating effect of income level on customer loyalty for a fundamental obligation that airlines should follow, whereas there was no moderating effect of income level on customer response for the desired responsibilities that airlines can voluntarily enforce. In a future study, rather than assessing income itself, variables affecting income indirectly, such as occupation, can be a significant socio-economic variable that moderates the effect of desired responsibilities on customer loyalty. Individuals in certain occupational groups, for example, public officers or teachers, are likely to have a higher moral standard for private enterprises.

Third, we surveyed passengers of Korean nationality who visited Incheon International Airport in South Korea. Although Incheon airport is one of the largest airports in the world serving 128 international destinations, expanding the scope of the survey subjects would help improve the generalization of the current findings with larger samples in different nations.

Fourth, a replication of this study during different seasons would increase the external validity of the model in the current study. As previous research has suggested, seasonality is a key feature of tourism [81]. We conducted this survey during the period of late fall to early winter. Usually, airplane ticket prices are the most expensive in June, August, and December, and the frequency of flights is the highest this season as well [82]. Prior research found that levels of consumer satisfaction with airport service at off-season could vary from that at peak season [83]. Although this survey was conducted at a major international airport, which has fewer fluctuations in the number of flights compared to smaller airports [82], future studies should support the results of the current research more robustly via surveys covering all seasons.

\section{Conclusions}

In conclusion, CSR is an essential part of corporations' efforts to improve customer loyalty and the airline industry is no exception. In fact, the airline industry is especially under more pressure to be socially responsible due to their large carbon footprint, and many airlines have put a variety of CSR initiatives in place. However, there is a lack of research breaking down which dimensions of CSR have a bigger impact on customer loyalty. Our study reveals that, among the two different types of CSR initiatives, desired CSR increased customer loyalty. In addition, the moderator variables of income 
and the level of formal education had significant effects. Regarding required CSR, customers with higher levels of either income or formal education showed increased customer loyalty. For desired CSR, only customers with higher levels of formal education showed significantly increased customer loyalty. Therefore, the current study not only gives a practical guide for those who are working in the airline industry field but also contributes critically to the CSR literature in the airline industry.

Author Contributions: Conceptualization, S.S.L., Y.K., and T.R. Methodology, T.R. Formal analysis, T.R. Investigation, T.R. Data curation, T.R. Writing-original draft preparation, S.S.L., Y.K., and T.R. Writing-review and editing, S.S.L., Y.K., and T.R. Supervision, T.R. All authors have read and agreed to the published version of the manuscript.

Funding: This research was funded by a grant from the Center for Happiness Studies, Seoul National University (0404-20190002).

Acknowledgments: This work was supported by the Soonchunhyang University Research Fund.

Conflicts of Interest: The authors declare no conflict of interest.

\section{References}

1. Han, H.; Yu, J.; Kim, W. Environmental corporate social responsibility and the strategy to boost the airline's image and customer loyalty intentions. J. Travel Tour. Mark. 2019, 36, 371-383. [CrossRef]

2. Hagmann, C.; Semeijn, J.; Vellenga, D.B. Exploring the green image of airlines: Passenger perceptions and airline choice. J. Air Transp. Manag. 2015, 43, 37-45. [CrossRef]

3. Kim, J.J.; Kim, K.; Hwang, J. Self-enhancement driven first-class airline travelers' behavior: The moderating role of third-party certification. Sustainability 2019, 11, 3285. [CrossRef]

4. Jaiswal, D.; Kant, R. Green purchasing behaviour: A conceptual framework and empirical investigation of Indian consumers. J. Retail. Consum. Serv. 2018, 41, 60-69. [CrossRef]

5. Mustonen, N.; Karjaluoto, H.; Jayawardhena, C. Customer environmental values and their contribution to loyalty in industrial markets. Bus. Strategy Environ. 2016, 25, 512-528. [CrossRef]

6. Peng, W.; Xin, B.; Kwon, Y. Optimal strategies of product price, quality, and corporate environmental responsibility. Int. J. Environ. Res. Public Health 2019, 16, 4704. [CrossRef]

7. Yang, A.S.; Baasandorj, S. Exploring CSR and financial performance of full-service and low-cost air carriers. Financ. Res. Lett. 2017, 23, 291-299. [CrossRef]

8. Niu, S.-Y.; Liu, C.-L.; Chang, C.-C.; Ye, K.-D. What are passenger perspectives regarding airlines' environmental protection? An empirical investigation in Taiwan. J. Air Transp. Manag. 2016, 55, 84-91. [CrossRef]

9. Coles, T.; Fenclova, E.; Dinan, C. Tourism and corporate social responsibility: A critical review and research agenda. Tour. Manag. Perspect. 2013, 6, 122-141. [CrossRef]

10. Asatryan, R. The effect of CSR initiatives on customer loyalty in the airline industry. In Proceedings of the 7th WSEAS International Conference on Business Administration, Milan, Italy, 9-11 January 2013; pp. 66-71.

11. Lho, H.; Park, J.; Yu, J. The effects of corporate social responsibility (CSR) initiatives on brand image, brand prestige, and behavioral intention. Int. J. Tour. Hosp. Res. 2019, 33, 63-74.

12. Carroll, A.B. Carroll's pyramid of CSR: Taking another look. Int. J. Corp. Soc. Responsib. 2016, 1, 3. [CrossRef]

13. Carroll, A.B. A three-dimensional conceptual model of corporate performance. Acad. Manag. Rev. 1979, 4, 497-505. [CrossRef]

14. Carroll, A.B. The pyramid of corporate social responsibility: Toward the moral management of organizational stakeholders. Bus. Horiz. 1991, 34, 39-48. [CrossRef]

15. Lee, S.S.; Kim, Y.; Roh, T. Modified pyramid of CSR for corporate image and customer loyalty: Focusing on the moderating role of the CSR experience. Sustainability 2019, 11, 4745. [CrossRef]

16. Bowen, H.R. Graduate education in economics. Am. Econ. Rev. 1953, 43, 1-223.

17. Amatulli, C.; De Angelis, M.; Korschun, D.; Romani, S. Consumers' perceptions of luxury brands' CSR initiatives: An investigation of the role of status and conspicuous consumption. J. Clean. Prod. 2018, 194, 277-287. [CrossRef]

18. Lee, C.-K.; Kim, J.S.; Kim, J.S. Impact of a gaming company's CSR on residents' perceived benefits, quality of life, and support. Tour. Manag. 2018, 64, 281-290. [CrossRef] 
19. Kim, J.S.; Song, H.; Lee, C.-K.; Lee, J.Y. The impact of four CSR dimensions on a gaming company's image and customers' revisit intentions. Int. J. Hosp. Manag. 2017, 61, 73-81. [CrossRef]

20. Baden, D. A reconstruction of Carroll's pyramid of corporate social responsibility for the 21st century. Int. J. Corp. Soc. Responsib. 2016, 1, 8. [CrossRef]

21. Sun, W.; Stewart, J.; Pollard, D. Reframing corporate social responsibility. Reframing Corp. Soc. Responsib. Lessons Glob. Financ. Crisis 2010, 1, 3-19.

22. Visser, W. Revisiting Carroll's CSR pyramid. In Corporate Citizenship in Developing Countries: New Partnership Perspectives; Huniche, M., Rahbek Pedersen, E., Eds.; Copenhagen Business School Press: Herndon, VA, USA, 2006.

23. Wagner-Tsukamoto, S. In search of ethics: From Carroll to integrative CSR economics. Soc. Responsib. J. 2019, 15, 469-491. [CrossRef]

24. Chang, H.-H.; Lu, L.-C. Actively persuading consumers to enact ethical behaviors in retailing: The influence of relational benefits and corporate associates. J. Bus. Ethics 2019, 156, 399-416. [CrossRef]

25. Tencati, A.; Misani, N.; Castaldo, S. A qualified account of supererogation: Toward a better conceptualization of corporate social responsibility. Bus. Ethics Q. 2020. [CrossRef]

26. Cowper-Smith, A.; de Grosbois, D. The adoption of corporate social responsibility practices in the airline industry. J. Sustain. Tour. 2011, 19, 59-77. [CrossRef]

27. Chen, F.-Y.; Chang, Y.-H.; Lin, Y.-H. Customer perceptions of airline social responsibility and its effect on loyalty. J. Air Transp. Manag. 2012, 20, 49-51. [CrossRef]

28. Lee, E.M.; Park, S.-Y.; Lee, H.J. Employee perception of CSR activities: Its antecedents and consequences. J. Bus. Res. 2013, 66, 1716-1724. [CrossRef]

29. Montgomery, C.; Stone, G. Revisiting consumer environmental responsibility: A five nation cross-cultural analysis and comparison of consumer ecological opinions and behaviors. Int. J. Manag. Mark. Res. 2009, 2, 35-58.

30. Stanisavljević, M. Does customer loyalty depend on corporate social responsibility? Naše Gospod. Our Econ. 2017, 63, 38-46. [CrossRef]

31. Fatma, M.; Rahman, Z.; Khan, I. Building company reputation and brand equity through CSR: The mediating role of trust. Int. J. Bank Mark. 2015, 33, 840-856. [CrossRef]

32. Chung, K.-H.; Yu, J.-E.; Choi, M.-G.; Shin, J.-I. The effects of CSR on customer satisfaction and loyalty in China: The moderating role of corporate image. J. Econ. Bus. Manag. 2015, 3, 542-547. [CrossRef]

33. Kandampully, J.; Suhartanto, D. Customer loyalty in the hotel industry: The role of customer satisfaction and image. Int. J. Contemp. Hosp. Manag. 2000, 12, 346-351. [CrossRef]

34. Anisimova, T.A. The effects of corporate brand attributes on attitudinal and behavioural consumer loyalty. J. Consum. Mark. 2007, 24, 395-405. [CrossRef]

35. Bodet, G. Customer satisfaction and loyalty in service: Two concepts, four constructs, several relationships. J. Retail. Consum. Serv. 2008, 15, 156-162. [CrossRef]

36. Pérez, A.; del Bosque, I.R. The effect of corporate associations on consumer behaviour. Eur. J. Mark. 2013, 47, 218-238. [CrossRef]

37. Ailawadi, K.L.; Neslin, S.A.; Luan, Y.J.; Taylor, G.A. Does retailer CSR enhance behavioral loyalty? A case for benefit segmentation. Int. J. Res. Mark. 2014, 31, 156-167. [CrossRef]

38. He, H.; Li, Y. CSR and service brand: The mediating effect of brand identification and moderating effect of service quality. J. Bus. Ethics 2011, 100, 673-688. [CrossRef]

39. Marin, L.; Ruiz, S.; Rubio, A. The role of identity salience in the effects of corporate social responsibility on consumer behavior. J. Bus. Ethics 2009, 84, 65-78. [CrossRef]

40. Atalik, O.; Eratik, B. A study on the effects of corporate social responsibility activities upon brand loyalty: Case of Turkish Airline customer. Int. J. Acad. Res. Econ. Manag. Sci. 2015, 4, 229-243.

41. Hair, J.F.; Black, W.C.; Babin, B.J.; Anderson, R.E.; Tatham, R.L. Multivariate Data Analysis, 7th ed.; Prentice Hall: Upper Saddle River, NJ, USA; Essex, UK, 1998; Volume 5.

42. Yaylali, M.; Çelik, A.; Dilek, Ö. Analyzing key socio-economic and socio-demographic drivers of domestic passengers' airline choice behavior in Turkey using multinomial and mixed logit models. Transp. Lett. 2016, 8, 121-130. [CrossRef]

43. Warburg, V.; Bhat, C.; Adler, T. Modeling demographic and unobserved heterogeneity in air passengers' sensitivity to service attributes in itinerary choice. Transp. Res. Rec. 2006, 1951, 7-16. [CrossRef] 
44. Yang, C.-W.; Lu, J.-L.; Hsu, C.-Y. Modeling joint airport and route choice behavior for international and metropolitan airports. J. Air Transp. Manag. 2014, 39, 89-95. [CrossRef]

45. Tyrrell, B.; Countryman, C.; Hong, G.S.; Cai, L.A. Determinants of destination choice by Japanese overseas travelers. J. Travel Tour. Mark. 2001, 10, 87-100. [CrossRef]

46. Oyewole, P. Consumer's socio-demographic characteristics and satisfaction with services in the airline industry. Serv. Mark. Q. 2001, 23, 61-80. [CrossRef]

47. Chen, H.-T.; Chao, C.-C. Airline choice by passengers from Taiwan and China: A case study of outgoing passengers from Kaohsiung International Airport. J. Air Transp. Manag. 2015, 49, 53-63. [CrossRef]

48. Morton, C.; Caulfield, B.; Anable, J. Customer perceptions of quality of service in public transport: Evidence for bus transit in Scotland. Case Stud. Transp. Policy 2016, 4, 199-207. [CrossRef]

49. Clemes, M.D.; Ozanne, L.K.; Laurensen, W.L. Patients' perceptions of service quality dimensions: An empirical examination of health care in New Zealand. Health Mark. Q. 2001, 19, 3-22. [CrossRef] [PubMed]

50. Youn, S.; Kim, H. Antecedents of consumer attitudes toward cause-related marketing. J. Advert. Res. 2008, 48, 123-137. [CrossRef]

51. Tian, Z.; Wang, R.; Yang, W. Consumer responses to corporate social responsibility (CSR) in China. J. Bus. Ethics 2011, 101, 197-212. [CrossRef]

52. Al-Abdallah, G.M.; Ahmed, R.S. The impact of corporate social responsibility on customer loyalty in the Qatari telecommunication sector. J. Bus. Retail Manag. Res. 2018, 13, 253-268. [CrossRef]

53. Tilikidou, I. The effects of knowledge and attitudes upon Greeks' pro-environmental purchasing behaviour. Corp. Soc. Responsib. Environ. Manag. 2007, 14, 121-134. [CrossRef]

54. Park, S.J.; Choi, S.; Kim, E.J. The relationships between socio-demographic variables and concerns about environmental sustainability. Corp. Soc. Responsib. Environ. Manag. 2012, 19, 343-354. [CrossRef]

55. Rahim, R.A.; Jalaludin, F.W.; Tajuddin, K. The importance of corporate social responsibility on consumer behaviour in Malaysia. Asian Acad. Manag. J. 2011, 16, 119-139.

56. Bigsby, H.; Ozanne, L.K. The purchase decision: Consumers and environmentally certified wood products. For. Prod. J. 2002, 52, 100-105.

57. Moisescu, O.-I. Demographics-based differences in the relationship between perceived CSR and customer loyalty in the dairy products market. Manag. Mark. 2015, 10, 118-131. [CrossRef]

58. Dube, K.; Nhamo, G. Climate change and the aviation sector: A focus on the Victoria Falls tourism route. Environ. Dev. 2019, 29, 5-15. [CrossRef]

59. Masoud, N. How to win the battle of ideas in corporate social responsibility: The International Pyramid Model of CSR. Int. J. Corp. Soc. Responsib. 2017, 2, 1-22. [CrossRef]

60. Ohaka, J.; Ogaluzor, O.I. Corporate social responsibility accounting and the effect of donations on profitability of oil and gas companies in Nigeria. Int. J. Acad. Res. Account. Financ. Manag. Sci. 2018, 8, 265-276.

61. Suki, N.M.; Suki, N.M.; Azman, N.S. Impacts of corporate social responsibility on the links between green marketing awareness and consumer purchase intentions. Procedia Econ. Financ. 2016, 37, 262-268. [CrossRef]

62. Fadun, S.O. Corporate social responsibility (CSR) practices and stakeholders expectations: The Nigerian perspectives. Res. Bus. Manag. 2014, 1, 13-31. [CrossRef]

63. Ramasamy, B.; Yeung, M. Chinese consumers' perception of corporate social responsibility (CSR). J. Bus. Ethics 2009, 88, 119-132. [CrossRef]

64. Baughn, C.C.; Bodie, N.L.; McIntosh, J.C. Corporate social and environmental responsibility in Asian countries and other geographical regions. Corp. Soc. Responsib. Environ. Manag. 2007, 14, 189-205. [CrossRef]

65. Glavas, A.; Kelley, K. The effects of perceived corporate social responsibility on employee attitudes. Bus. Ethics Q. 2014, 24, 165-202. [CrossRef]

66. Liu, M.T.; Wong, I.A.; Shi, G.; Chu, R.; Brock, J.L. The impact of corporate social responsibility (CSR) performance and perceived brand quality on customer-based brand preference. J. Serv. Mark. 2014, 28, 181-194.

67. Mohr, L.A.; Webb, D.J. The effects of corporate social responsibility and price on consumer responses. J. Consum. Aff. 2005, 39, 121-147. [CrossRef]

68. Ramasamy, B.; Yeung, M.C.; Au, A.K. Consumer support for corporate social responsibility (CSR): The role of religion and values. J. Bus. Ethics 2010, 91, 61-72. [CrossRef]

69. Chin, W.W. The partial least squares approach to structural equation modeling. Mod. Methods Bus. Res. 1998, 295, 295-336. 
70. Bentler, P.M.; Raykov, T. On measures of explained variance in nonrecursive structural equation models. J. Appl. Psychol. 2000, 85, 125-131. [CrossRef]

71. Kock, N. Common method bias in PLS-SEM: A full collinearity assessment approach. Int. J. E-Collab. 2015, 11, 1-10. [CrossRef]

72. Kock, N.; Lynn, G. Lateral collinearity and misleading results in variance-based SEM: An illustration and recommendations. J. Assoc. Inf. Syst. 2012, 13, 546-580. [CrossRef]

73. Chang, D.-S.; Chen, S.-H.; Hsu, C.-W.; Hu, A.H. Identifying strategic factors of the implantation CSR in the airline industry: The case of Asia-Pacific airlines. Sustainability 2015, 7, 7762-7783. [CrossRef]

74. Lee, S.; Seo, K.; Sharma, A. Corporate social responsibility and firm performance in the airline industry: The moderating role of oil prices. Tour. Manag. 2013, 38, 20-30. [CrossRef]

75. Tsai, W.-H.; Hsu, J.-L. Corporate social responsibility programs choice and costs assessment in the airline industry-A hybrid model. J. Air Transp. Manag. 2008, 14, 188-196. [CrossRef]

76. Asatryan, R.; Březinová, O. Corporate social responsibility and financial performance in the airline industry in Central and Eastern Europe. Acta Univ. Agric. Silvic. Mendel. Brun. 2014, 62, 633-639. [CrossRef]

77. Park, E. Corporate social responsibility as a determinant of corporate reputation in the airline industry. J. Retail. Consum. Serv. 2019, 47, 215-221. [CrossRef]

78. Vo, T.T.; Xiao, X.; Ho, S.Y. How does corporate social responsibility engagement influence word of mouth on Twitter? Evidence from the airline industry. J. Bus. Ethics 2019, 157, 525-542. [CrossRef]

79. Lee, S.; Park, S.-Y. Financial impacts of socially responsible activities on airline companies. J. Hosp. Tour. Res. 2010, 34, 185-203. [CrossRef]

80. Kucukusta, D.; Denizci Guillet, B.; Chan, H.L. The effect of CSR practices on employee affective commitment in the airline industry. J. China Tour. Res. 2016, 12, 451-469. [CrossRef]

81. Papatheodorou, A. Civil aviation regimes and leisure tourism in Europe. J. Air Transp. Manag. 2002, 8, 381-388. [CrossRef]

82. Kraft, S.; Havlíková, D. Anytime? Anywhere? The seasonality of flight offers in Central Europe. Morav. Geogr. Rep. 2016, 24, 26-37. [CrossRef]

83. Kozak, M.; Rimmington, M. Tourist satisfaction with Mallorca, Spain, as an off-season holiday destination. J. Travel Res. 2000, 38, 260-269. [CrossRef] 